\title{
Health-related quality of life among persons with physical disabilities: a systematic review and meta-analysis
}

\section{Sandra Lima-Castro', Vanessa Blanco ${ }^{2 *}$, Patricia Otero $^{3}$, Lara López $^{4}$ \& Fernando L.Vázquez ${ }^{4}$}

'Faculty of Psychology, University of Cuenca, Ecuador, ${ }^{2}$ Department of Evolutionary and Educational Psychology, University of Santiago de Compostela, Spain, ${ }^{3}$ Department of Psychology, University of A Coruña, Spain, ${ }^{4}$ Department of Clinical Psychology and Psychobiology, University of Santiago de Compostela, Spain

- Received: 18 - 03 - 2020 . Accepted: 11 - 04 - 2020 . Avaliable online: 27 - 04 - 2020

ABSTRACT. Although research suggests that people with physical disabilities experience impacts to their health-related quality of life $(\mathrm{HRQL})$, there are no previous reviews or meta-analyses of studies that use appropriate assessment instruments in this population. The objective of this project was to conduct a systematic literature review and meta-analysis of studies that use the World Health Organization Quality of Life Questionnaire (WHOQOL-BREF) to evaluate HRQL in people with physical disabilities. We searched the PsycINFO, Medline, CINAHL and The Cochrane Library databases, identifying articles published through February 2020. The methodological quality of the studies was analyzed, and the pooled mean scores for each domain of the WHOQOL-BREF were calculated. Ten studies involving 2,048 people with physical disabilities were included. Their methodological quality was adequate. The pooled mean scores were 49.5 for the physical domain, 57.7 for the psychological domain, 58.2 for the social relations domain, and 55.5 for the environmental domain. The findings of this work confirm an impact of physical disabilities on the four HRQL domains in this population.

KEYWORDS: Health-Related Quality of Life; Physical Disability; WHOQOL-BREF; Meta-Analysis; Moderators.

Calidad de vida relacionada con la salud en personas con discapacidad física: Una revision sistemática y metanálisis

RESUMEN. Aunque la investigación sugiere que las personas con discapacidad física ven afectada su calidad de vida relacionada con la salud (CVRS), no existen trabajos de revisión y metanálisis previos empleando instrumentos de evaluación adecuados en esta población. El objetivo de este estudio fue realizar una revisión sistemática de la literatura y metanálisis de investigaciones que evaluaron la CVRS en personas con discapacidad física empleando el Cuestionario de Calidad de Vida de la Organización Mundial de la Salud (WHOQOLBREF). Se realizó una búsqueda en las bases de datos PsycINFO, Medline, CINAHL y The Cochrane Library, identificando artículos publicados hasta febrero de 2020. Se analizó la calidad metodológica de los estudios y se calcularon las puntuaciones medias agrupadas para cada dominio de la WHOQOL-BREF. Se incluyeron 10 estudios en los que participaron 2,048 personas con discapacidad física. Su calidad metodológica fue adecuada. Las puntuaciones medias agrupadas fueron de 49.5 para el dominio físico, 57.7 para el dominio psicológico, 58.2 para el dominio relaciones sociales y 55.5 para el dominio ambiente. Los hallazgos de este trabajo confirman una afectación de los cuatro dominios de la CVRS en esta población.

PALABRAS CLAVE: Calidad de Vida relacionada con la Salud, Discapacidad Física, WHOQOL-BREF, Metanálisis, Moderadores.

Globally, 15\% of adults have a disability, a figure that continues to grow not only due to aging populations but also to increases in various

\footnotetext{
${ }^{*}$ Correspondence: Vanessa Blanco.

Department of Evolutionary and Educational Psychology,

University of Santiago de Compostela, Spain.

Postcode: 15782, Santiago de Compostela, Spain.

E-mail:vanessa.blanco@usc.es
}

(C) 2020 Sociedad Universitaria de Investigación en Psicologíay Salud. Publicado por Consejo General de Colegios Oficiales de Psicólogos, España. Este es un artículo Open Access
bajo la CC BY-NC-ND licencia (http://creativecommons.org/licencias/by-nc-nd/4.0/).

Citar como/Cite as: Lima-Castro, S., Blanco, V., Otero, P., López, L. y Vázquez, F. L. (2020). Health-related quality of life among persons with physical disabilities: a systematic review and meta-analysis. Revista Iberoamericana de Psicología y Salud, $17(2), 82-102$. Doi: https://doi.org/10.23923/i.rips.2020.02.037 chronic health problems that are potentially disabling (World Health Organization and The World Bank, 2010). The origins of physical disabilities are diverse and include trauma (e.g., spinal cord injury, brain injury), congenital and acquired conditions (e.g., neurological or musculoskeletal disorders), and stroke, among other causes (Law et al., 2014; Murray et al., 2012) 
Some studies have found that people with physical disabilities report lower levels of HealthRelated Quality of Life (HRQL) than the general population (e.g., Barker et al., 2009). HRQL refers to the individual's perception of their position in life within the cultural context and value system in which they live, and with respect to their goals, expectations, norms, and concerns (The WHOQOL Group, 1995). This complex concept encompasses four different domains: 1) physical, related to restrictions on activities of daily living, dependence on medications, energy and fatigue, mobility, pain, sleep, and work; 2) psychological, which refers to self-image, feelings, self-esteem, spirituality, thinking, learning, memory, and concentration; 3) social relations, related to personal interactions, social support, and sexual activity; and 4) environmental, which refers to safety, the physical environment, financial resources, access to information, leisure, home, health care, and transportation (The WHOQOL Group, 1998). Thus, people affected by a physical disability may experience significant difficulties in various aspects of $H R Q L$, including problems in performing daily activities (e.g., Liem, McColl, King, \& Smith, 2004); chronic pain (e.g., Carter, Miró, Abresch, El-Abassi, \& Jensen, 2012); anxiety, depression (Jones et al., 2014); and/ or limitations on social participation and social support (Craig et al., 2015). In addition, they frequently suffer from the presence of barriers in the environment, such as an unavailability of health care and transportation (Whiteneck et al., 2004). Because of all this, evaluation of HRQL should be central to the overall assessment of people with physical disabilities.

Several previous review papers have analyzed HRQL among people with physical conditions that can cause disability (Passier, Visser-Meily, Rinkel, Lindeman, \& Post, 2013; Sakakibara, Hitzig, Miller, \& Eng, 2012; Sinha \& Van Den Heuvel, 2011; van Leeuwen, Kraaijeveld, Lindeman, \& Post, 2012; Yang et al., 2016). However, these reviews have a number of limitations, such as a failure to provide information for the different domains of HRQL (e.g., van Leeuwen et al., 2012); analysis of HRQL in association with a disease, regardless of whether or not it results in physical disability (Sakakibara et al., 2012; Sinha \& Van Den Heuvel, 2011; van Leeuwen et al., 2012; Yang et al., 2016); or use of HRQL assessment instruments for which there was no evidence of adequate psychometric properties in the population under study (e.g., Passier et al., 2013; Sakakibara et al., 2012). In addition, such reviews were unable to perform meta-analyses due to the heterogeneity of the instruments used to assess HRQL (e.g., Passier et al., 2013; Sinha \& Van Den Heuvel, 2011; van Leeuwen et al., 2012). Therefore, as far as we know there are no existing meta-analyses that synthesize and integrate the results of studies evaluating HRQL in people with physical disabilities and that take into account the different domains of this measure.

Among the most widely accepted tools for assessing HRQL is the World Health Organization Quality of Life Questionnaire (WHOQOL-BREF; The WHOQOL Group, 1998). This instrument has been adapted to different cultures, and has adequate internal consistency, test-retest reliability, sensitivity to change, and discriminant and construct validity in both healthy populations and in patients with diseases associated with disability (Hill, Noonan, Sakakibara, \& Miller, 2010; Skevington \& Epton, 2018).

Considering the above, it is necessary to synthesize information from studies aimed at estimating $H R Q L$ in persons with physical disabilities with an appropriate assessment instrument that provides information on the four defining domains of this construct; to evaluate studies that are focused on the evaluation of participants with physical disabilities and not only those diagnosed with a certain disease; and assess previous research that demonstrates methodological quality. Therefore, this systematic review and meta-analysis aims to systematically analyze all available published articles that evaluated HRQL in people with physical disabilities, providing pooled mean scores for the four domains of WHOQOL-BREF. We then explore the potential reasons for heterogeneity among the studies.

\section{MATERIALS AND METHODS}

This systematic literature review and metaanalysis was developed in accordance with the guidelines of the Meta-analyses of Observational 
Studies in Epidemiology-Checklist (MOOSE; Stroup et al., 2000). The protocol for this review was registered in the International Prospective Registry of Systematic Reviews (PROSPERO) (CRD42018108649).

\section{-SEARCH STRATEGY}

Studies published through February 2020 were obtained from a systematic search of the literature in the Medline, PsycINFO, CINAHL, and The Cochrane Library databases. The search terms used were ("quality of life" OR "health related quality of life" OR QOL OR HRQL) AND ("physical disabilit*" OR disabilit* OR "disabled") AND (WHOQOL-BREF) AND (cross-sectional OR cohort). Studies in both Spanish and English were included. Additional studies identified through manual searches, follow-up of references cited in other studies, and relevant previous bibliographic reviews were also included.

\section{-STUDY SELECTION PROCEDURE}

After eliminating duplicates, the titles, abstracts, and keywords of the identified studies were examined to determine their relevance. Full texts of the articles considered relevant were obtained, and two independent reviewers assessed whether they met the inclusion or exclusion criteria. Any disagreement was discussed at a consensus meeting. If no consensus was reached, a third independent reviewer made the decision. The steps in the selection process are described in a PRISMA flowchart (Figure 1).

The selected studies met the following inclusion criteria: (a) use of a cross-sectional or cohort design; (b) aimed at assessing HRQL in adults with physical disabilities; (c) presence of physical disability was determined through appropriate diagnostic criteria; and (c) data for the four WHOQOL-BREF domains was provided, presented as means $(M)$ and standard deviations (SD) or standard error of the means (SEM).

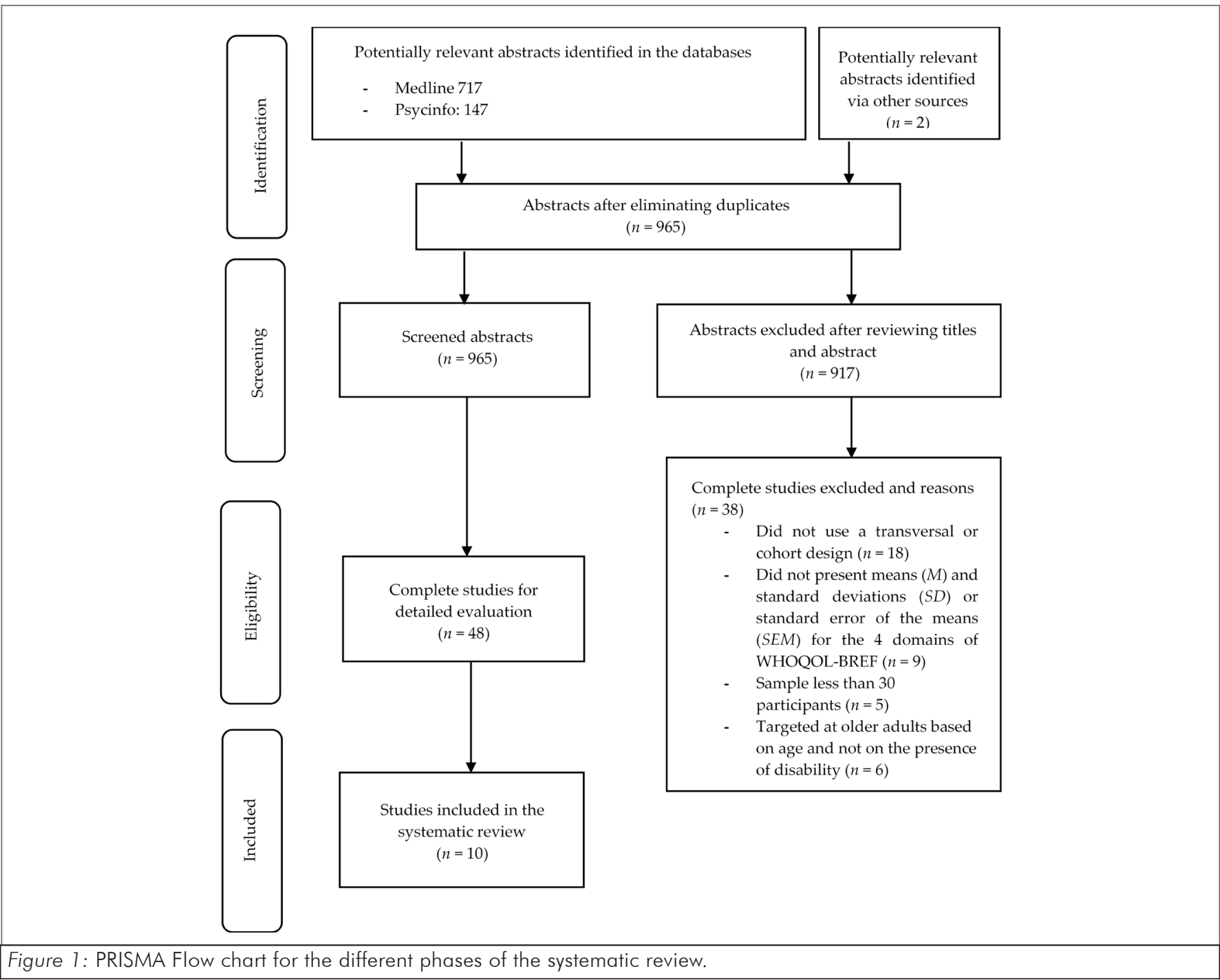


Studies meeting the following criteria were excluded: (a) sample size of $<30$ subjects; (b) aimed at older adults based on age and not on the presence of disability; (c) study objective was to evaluate the psychometric properties of HRQL or disability assessment scales; and (d) designed to evaluate interventions aimed at improving HRQL in people with disabilities.

\section{- DATA EXTRACTION (SELECTION AND CODING)}

The data from the selected articles were extracted independently by two evaluators using a standardized data extraction protocol, then coded according to a manual, as suggested by the guidelines of the MOOSE (Stroup et al., 2000).

The information extracted from the selected studies included the study identification; participant characteristics (number, age, percentage of women, study region [the Americas, Europe, Asia, Africa]), health problems causing physical disability (spinal cord injury, stroke, multiple sclerosis, Parkinson's, chronic low back pain, adhesive capsulitis, nervous system diseases, musculoskeletal system and connective tissue diseases), recruitment scope (health care setting, community, or mixed [hospital-association]); methodological characteristics (design [transversal or cohort], sample size estimated, random selection of the sample, recruitment method [from the health care sector, through organizational databases, or through medical records, and contact with associations], inclusion and exclusion criteria [reported/not], response rate [reported/not], ethical approval [reported/not], informed consent [reported/not], disability assessment instrument [used/not]); risk of biases, and the mean scores and standard deviations for the four domains of the WHOQOL-BREF. The authors were contacted for additional data if incomplete data were detected.

In no less than one week after the initial coding, each evaluator recoded $50 \%$ of their own previously coded studies for intraevaluator consistency and $50 \%$ of the previously coded studies by the other evaluator for interevaluator consistency. The fidelity of coding for the categorical variables was evaluated via true Kappa $\left({ }^{-} \kappa\right)$, using the categorical content analysis technique and the statistical solution of Fariña, Arce, and Novo (2002). If the coding was the same between evaluators or within evaluators, agreement was coded as 1 . If one evaluator recorded one category and the other recorded a different one, or if the same evaluator recorded one category at the first coding and did not record it at the subsequent coding, it was coded as 1 . If both evaluators, or the same evaluator at both points in time, coded within the same category but in a different way, disagreement was coded as 2 . The intra- and inter-evaluator agreement for all categories was exact $\left({ }^{-} \kappa=1\right)$. Also, one of the evaluators had a high degree of agreement (concordance) with the other evaluators in the categorical analysis for a previous metaanalysis (Vázquez et al. (2018), indicating a high degree of inter-contextual consistency. These findings demonstrate a high degree of fidelity in the coding (Monteiro, Vázquez, Seijo, \& Arce, 2018).

\section{- EVALUATION OF RISK OF BIAS (METHODOLOGICAL QUALITY)}

Two researchers independently assessed the risk of bias in each study using the RTI Item Bank tool (Viswanathan, Berkman, Dryden, \& Hartling, 2013). This tool provides a list of 13 questions to evaluate confounding factors or the risk of bias in observational studies, providing instructions on which items to use based on the characteristics of the studies to be evaluated. Four were selected for this work, aimed at assessing execution bias (question 2); information bias (question 6); global credibility (question 11); and selection bias (question 13).

A score was assigned depending on the number of items completed for each study, which were classified into: low methodological quality/high risk of bias (0 to .40); moderate methodological quality/moderate risk of bias (.41 to .70); or high methodological quality/ low risk of bias (.71 to 1.0), multiplying the values by 100 . The cut-off scores were based on previous review and meta-analysis studies, following the criteria of Deeks et al. (2003). 


\section{-STRATEGY FOR DATA SYNTHESIS}

The pooled mean scores for the four domains of the WHOQOL-BREF were estimated, with their 95\% confidence intervals $(\mathrm{Cl})$, using the inverse-variance method. For those studies that did not provide the WHOQOL-BREF scores in a 0-100 format, the scores were transformed according to its protocol.

The $1^{2}$ test was used to evaluate the heterogeneity between the studies, using a fixedeffects model if there was no heterogeneity $\left(1^{2}\right.$ $<50 \%$ ) or a random-effects model if there was heterogeneity $\left(I^{2}>50 \%\right)$.

The Egger test was used to investigate the presence of publication bias, with $p<.05$ being considered statistically significant. Subgroup analyses were performed when heterogeneity was detected. All statistical analyses were performed using Comprehensive Meta-analysis Version 2.0 software (Borenstein, Hedges, Higgins, \& Rothstein, 2005).

To determine the statistical significance between the pooled mean scores of the WHOQOL-BREF domains as well as the moderation analyses, an analysis was conducted to examine overlaps between each of the scores and the confidence intervals for the means, according to the procedure described by Redondo, Fariña, Seijo, Novo, and Arce (2019).

\section{-SUBGROUP ANALYSIS}

To analyze variance in the moderating variables in relation to the four domains of the WHOQOL-BREF, meta-ANOVAs were used for the categorical variables, and meta-regressions for the quantitative variables, using the IBM $®$ SPSS $®$ (Version 21.0) statistical software.

\section{RESULTS}

\section{-SELECTION OF STUDIES}

After eliminating duplicates, 965 articles were identified. Of these, the full texts of 48 articles were evaluated for inclusion (Figure 1). Additional data were requested from the authors of 8 studies and were received for 2 of them (Choi et al., 2013; Estrella Castillo \& Gomez-de-Regil, 2016).

Table 1

Main characteristics of the articles included

\begin{tabular}{|c|c|c|c|c|}
\hline Reference Country & Objective & $\begin{array}{l}\text { Sample } \\
(N, \% \\
\text { women) }\end{array}$ & Design & $\begin{array}{l}\text { Health problem } \\
\text { causing physical } \\
\text { disability }\end{array}$ \\
\hline $\begin{array}{l}\text { Badenhorst et al. (2018) } \\
\text { South Africa }\end{array}$ & Investigate the $\mathrm{HRQL}$ and factors associated among people with $\mathrm{SCl}$. & $\begin{array}{c}N=90 \\
0 \%\end{array}$ & $\mathrm{x}$ & $\mathrm{SCl}$ \\
\hline $\begin{array}{l}\text { Chang et al. (2012) } \\
\text { Taiwan }\end{array}$ & Identify the factors that influence the individual's QL after SCl. & $\begin{array}{c}N=341 \\
58.0 \%\end{array}$ & $\mathrm{x}$ & $\mathrm{SCl}$ \\
\hline $\begin{array}{l}\text { Choi et al. (2013) } \\
\text { South Korea }\end{array}$ & $\begin{array}{l}\text { Investigate associations of emotional incontinence after stroke with } \\
\text { psychiatric symptoms and HRQL. }\end{array}$ & $\begin{array}{c}N=423 \\
41.9 \%\end{array}$ & $\mathrm{x}$ & Recent stroke \\
\hline $\begin{array}{l}\text { Dajpratham and } \\
\text { Kongkasuwan (2011) } \\
\text { Thailand }\end{array}$ & $\begin{array}{l}\text { Assess the QL of patients with traumatic } \mathrm{SCl} \text { and identify factors related } \\
\text { to good levels of QL. }\end{array}$ & $\begin{array}{l}N=67 \\
26.9 \%\end{array}$ & $\mathrm{x}$ & $\mathrm{SCl}$ \\
\hline $\begin{array}{c}\text { Estrella-Castillo and } \\
\text { Gomez-de-Regil (2016) } \\
\text { Mexico }\end{array}$ & $\begin{array}{l}\text { Evaluate the } Q \mathrm{~L} \text { of patients with neuromusculoskeletal and movement- } \\
\text { related functional disabilities. Analyze the effect of the medical } \\
\qquad \text { condition. }\end{array}$ & $\begin{array}{c}N=330 \\
62.4 \%\end{array}$ & $\mathrm{x}$ & $\begin{array}{l}\text { Neuromusculoskeletal } \\
\text { and movement-related } \\
\text { functional disabilities }\end{array}$ \\
\hline $\begin{array}{l}\text { Jeong et al. (2012) } \\
\text { South Korea }\end{array}$ & $\begin{array}{l}\text { Investigate the determinants of } Q L \text { during the acute phase after a } \\
\text { stroke. }\end{array}$ & $\begin{array}{c}N=422 \\
42.2 \%\end{array}$ & C & Ischemic stroke \\
\hline $\begin{array}{l}\text { Lucas-Carrasco et al. } \\
\text { (2011) - Spain }\end{array}$ & Examine QL in people with neurodegenerative disorders (ND). & $\begin{array}{c}N=149 \\
50.3 \%\end{array}$ & $\mathrm{x}$ & $\begin{array}{l}\text { ND (multiple sclerosis } \\
\text { and Parkinson's) }\end{array}$ \\
\hline $\begin{array}{l}\text { Phillips et al. } \\
\text { (2009) - Scotland }\end{array}$ & $\begin{array}{l}\text { Investigate the role of attention deficit and emotion regulation in } \\
\text { predicting HRQL in patients with multiple sclerosis. }\end{array}$ & $\begin{array}{l}N=86 \\
63.0 \%\end{array}$ & $\mathrm{x}$ & Multiple sclerosis \\
\hline $\begin{array}{l}\text { Rassi-Fernandes et al. } \\
\text { (2015) Brazil }\end{array}$ & $\begin{array}{c}\text { Determine the correlation between functional disability and QL of } \\
\text { patients with adhesive capsulitis. }\end{array}$ & $\begin{array}{l}N=43 \\
53.5 \%\end{array}$ & C & Adhesive capsulitis \\
\hline $\begin{array}{l}\text { Stefane et al. (2013) } \\
\text { Brazil }\end{array}$ & $\begin{array}{l}\text { Evaluate pain perception, disability and HRQL in patients with chronic } \\
\text { low back pain. }\end{array}$ & $\begin{array}{l}N=97 \\
69.1 \%\end{array}$ & $\mathrm{x}$ & $\begin{array}{l}\text { Chronic low back } \\
\text { pain }\end{array}$ \\
\hline
\end{tabular}

Note: $\mathrm{X}=$ Cross-sectional; $\mathrm{C}=$ cohort; $\mathrm{SCl}=$ Spinal Cord Injury 
The inclusion and exclusion criteria eliminated 38 articles: 18 due to the type of design; 9 that presented no means $(M)$ and standard deviations (SD) or standard error of the means (SEM) for the 4 domains of the WHOQOL-BREF; 6 that were aimed at older adults based on age and not on the presence of a disability; and 5 with sample sizes $<30$ participants. In the end, 10 studies were included, whose main characteristics are presented in Table 1.

\section{-DESCRIPTIVE CHARACTERISTICS OF THE INCLUDED STUDIES}

The 10 studies included 2,048 participants with physical disabilities, with an average sample size of 235.4 participants (SD = 178.8). The sample sizes ranged from 43 (Rassi-Fernandes, 2015) to 423 (Choi et al., 2013). The mean age of the participants was 51.2 (SD $=10.0$ ) years, ranging from 36.5 (Dajpratham \& Kongkasuwan, 2011) to 64.5 years old (Choi et al., 2013; Jeong et al., 2012). The average percentage of women was $50.9 \%$, ranging from 0\% (Badenhorst, Brown, Lambert, Mechelen, \& Verhagen, 2018) to 69.1\% (Stefane, Munari dos Santos, Marinovic y Hortense, 2013).

Of the studies included in the review, 40\% were conducted in Asia (Chang, Wang, Jang, \& Wang, 2012; Choi et al., 2013; Dajpratham \& Kongkasuwan, 2011 ; Jeong et al., 2012), 30\% in the Americas (Estrella-Castillo \& Gómez-deRegil, 2016; Rassi-Fernandes, 2015; Stefane et al., 2013;), 20\% in Europe (Lucas-Carrasco et al., 2011; Phillips et al., 2009) and 10\% in Africa (Badenhorst et al., 2018).

In relation to the health problems causing the physical disability, $30 \%$ of the studies examined spinal cord injuries (Badenhorst et al., 2018; Chang et al., 2012; Dajpratham \& Kongkasuwan, 2011); 20\% stroke (Choi et al., 2013; Jeong et al., 2012); 10\% multiple sclerosis (Phillips et al., 2009); 10\% adhesive capsulitis (Rassi-Fernandes, 2015); 10\% chronic low back pain (Stefane et al., 2013); 10\% diseases of the nervous system or diseases of the musculoskeletal system and connective tissue (Estrella-Castillo \& Gómez-de-Regil, 2016) and $10 \%$ multiple sclerosis and Parkinson's disease (Lucas-Carrasco et al., 2011).
Regarding the area in which recruitment was conducted, $70 \%$ of the studies recruited participants through health care providers (Choi et al., 2013; Dajpratham \& Kongkasuwan, 2011; Estrella-Castillo \& Gómez-de-Regil, 2016; Jeong et al., 2012; Lucas-Carrasco et al., 2011 ; Rassi-Fernandes, 2015; Stefane et al., 2013); 20\% at the community level (Badenhorst et al., 2018; Phillips et al., 2009); and 10\% through both avenues (Chang et al., 2012).

\section{- METHODOLOGICAL CHARACTERISTICS OF THE STUDIES}

A cross-sectional design was used in $80 \%$ of the studies (Badenhorst et al., 2018; Chang et al., 2012; Choi et al., 2013; Dajpratham \& Kongkasuwan, 2011 ; Estrella-Castillo \& Gómezde-Regil, 2016; Lucas-Carrasco et al., 2011; Phillips et al., 2009; Stefane et al., 2013) while 20\% used a cohort design (Jeong et al., 2012; Rassi-Fernandes, 2015).

None of the studies estimated the needed sample size nor selected the sample randomly. In $70 \%$ of the cases, participants were recruited by professionals in the health care field (Choi et al., 2013; Dajpratham \& Kongkasuwan, 2011; Estrella-Castillo \& Gómez-de-Regil, 2016; Jeong et al., 2012; Lucas-Carrasco et al., 2011 ; RassiFernandes, 2015; Stefane et al., 2013); in 20\% they were recruited through databases of official organizations that serve people with disabilities (Badenhorst et al., 2018; Phillips et al., 2009) and in $10 \%$ potential participants were members of an association and drawn from the medical records of a hospital (Chang et al., 2012).

All the studies established clear inclusion criteria and $80 \%$ of the studies specified exclusion criteria (Badenhorst et al., 2018; Choi et al., 2013; Dajpratham \& Kongkasuwan, 2011; Estrella-Castillo \& Gómez-de-Regil, 2016; Jeong et al., 2012; Lucas-Carrasco et al., 2011 ; RassiFernandes, 2015; Stefane et al., 2013), while 20\% did not explicitly state them (Chang et al., 2012; Phillips et al., 2009).

The percentage of people who agreed to participate was calculated based on the data provided. In $60 \%$ of the studies it was possible to calculate the response rate (Badenhorst et al., 2018; Chang et al., 2012; Choi et al., 2013; 
Estrella-Castillo \& Gómez-de-Regil, 2016; Jeong et al., 2012; Phillips et al., 2009), but 40\% did not provide this data (Dajpratham \& Kongkasuwan, 2011; Lucas-Carrasco et al., 2011; RassiFernandes, 2015; Stefane et al., 2013). The response rate varied between 52\% (Phillips et al., 2009) and 95\% (Jeong et al., 2012).

Ninety percent of the studies reported obtaining ethical approval and informed consent (Badenhorst et al., 2018; Chang et al., 2012; Choi et al., 2013; Dajpratham \& Kongkasuwan, 2011; Estrella-Castillo \& Gómez-de-Regil, 2016; Jeong et al., 2012; Lucas-Carrasco et al., 2011 ; Phillips et al., 2009; Rassi-Fernandes, 2015) while 10\% did not report on this aspect (Stefane et al., 2013). Finally, $90 \%$ of the studies used instruments to assess disability (Badenhorst et al., 2018; Chang et al., 2012; Choi et al., 2013; Rassi-Fernandes, 2015; Daipratham \& Kongkasuwan, 2011; Jeong et al., 2012; Lucas-Carrasco et al., 2011 ; Phillips et al., 2009; Stefane et al., 2013), while $10 \%$ used other appropriate diagnostic criteria (Estrella-Castillo \& Gómez-de-Regil, 2016).

\section{- QUALITY ASSESSMENT AND RISK OF BIAS}

The score for the studies on the RTI (Viswanathan et al., 2013) ranged from 4/4 (low risk of bias on all items: Badenhorst et al., 2018; Choi et al., 2013; Daijpratham et al., 2011; Jeong et al., 2012; Stefane et al. 2013 ) to $3 / 4$ (low risk of bias on $3 / 4$ items evaluated: Chang et al., 2012; EstrellaCastillo \& Gomez-de-Regil, 2016; LucasCarrasco et al., 2011; Phillips et al., 2009; Rassi-Fernandes, 2015). The risk of bias assessment for each of the studies is shown in Table 2.

\section{- GLOBAL HEALTH-RELATED QUALITY OF LIFE}

Figure 2 shows the mean scores for each study, the pooled means for the four domains of the WHOQOL-BREF, the 95\% confidence intervals $(\mathrm{Cl})$, and the results of the $1^{2}$ test for each domain. The pooled mean scores for the physical domain were 49.5,

Table 1

Main characteristics of the articles included

\begin{tabular}{|c|c|c|c|c|c|c|c|}
\hline $\begin{array}{l}\text { Reference } \\
\text { Country }\end{array}$ & $\begin{array}{c}\text { Execution } \\
\text { Bias }\end{array}$ & $\begin{array}{c}\text { Information } \\
\text { Bias }\end{array}$ & $\begin{array}{c}\text { Global } \\
\text { credibility }\end{array}$ & $\begin{array}{l}\text { Selection } \\
\text { Bias }\end{array}$ & Total & Score & Decision \\
\hline $\begin{array}{l}\text { Badenhorst et al. } \\
\text { (2018) }\end{array}$ & No & No & No & No & $4 / 4$ & 100 & LRB \\
\hline Chang et al. (2012) & Yes & No & No & No & $3 / 4$ & 75 & LRB \\
\hline Choi et al. (2013) & No & No & No & No & $4 / 4$ & 100 & LRB \\
\hline $\begin{array}{l}\text { Daijpratham et al. } \\
\qquad(2011)\end{array}$ & No & No & No & No & $4 / 4$ & 100 & LRB \\
\hline $\begin{array}{c}\text { Estrella-Castillo \& } \\
\text { Gomez-de-Regil } \\
(2016)\end{array}$ & No & No & No & Yes & $3 / 4$ & 75 & LRB \\
\hline Jeong et al. (2012) & No & No & No & No & $4 / 4$ & 100 & LRB \\
\hline $\begin{array}{l}\text { Lucas-Carrasco et } \\
\text { al. (2010) }\end{array}$ & No & No & No & Yes & $3 / 4$ & 75 & LRB \\
\hline Phillips et al. (2009) & No & No & No & Yes & $3 / 4$ & 100 & LRB \\
\hline $\begin{array}{c}\text { Rassi-Fernandes } \\
\text { (2015) }\end{array}$ & No & No & No & Yes & $3 / 4$ & 75 & LRB \\
\hline Stefane et al. (2013) & No & No & No & No & $4 / 4$ & 100 & LRB \\
\hline
\end{tabular}


for the psychological domain 57.7, for the social relations domain 58.2, and for the environmental domain 55.5.

Comparatively, significant differences were found between the physical domain score and the rest of the domains (i.e., Cls overlapped for all domains except for the physical domain).

\section{- RESULTS OF THE SUBGROUP ANALYSIS}

Considering the heterogeneity among the included studies $\left(I^{2}>90 \%\right)$, the question of whether the pooled mean scores for the four domains of the WHOQOL-BREF varied as a function of potential moderating variables was explored. Table 3 presents the results of the analysis of variance for the moderating variables. For each of the HRQL domains, it was found that study region; health problem causing disability; recruitment scope; study design; recruitment method; reporting of exclusion criteria, response rate, ethical approval, and informed consent; and use of a disability assessment instrument acted as moderating variables.

PHYSICAL DOMAIN. Better scores were found if the study region was Africa, the disability was due to musculoskeletal disease, the recruitment scope was community, the design was cross-sectional, participants were contacted through a database, exclusion criteria and response rate were reported, ethics approval and informed consent were obtained, and disability was assessed through other appropriate diagnostic criteria ( $p<$ $.05)$.

\begin{tabular}{|c|c|c|c|c|c|}
\hline \multicolumn{6}{|l|}{ Physical Domain } \\
\hline Study A uthors & Mean & $\begin{array}{l}\text { Lower } \\
\text { Bound }\end{array}$ & $\begin{array}{l}\text { Upper } \\
\text { Bound }\end{array}$ & & $\%$ weighting \\
\hline Badenhorst et al. (2018) & 66.900 & 63.491 & 70.309 & & 8.09 \\
\hline Chang et al. (2012) & 48.440 & 47.152 & 49.726 & & 8.76 \\
\hline Choi et al. (2013) & 47.461 & 45.941 & 48.981 & & 8.72 \\
\hline $\begin{array}{l}\text { Dajpratham and } \\
\text { Kongk asuw an (2011) } \\
\end{array}$ & 46.040 & 43.791 & 48.289 & & 8.52 \\
\hline $\begin{array}{l}\text { Estrella-Castillo and } \\
\text { Gómez-de-Regil (2015) a }\end{array}$ & 57.780 & 56.657 & 58.903 & & 8.79 \\
\hline $\begin{array}{l}\text { Estralla-Castillo and } \\
\text { Gomez-de-Regil (2015) b }\end{array}$ & 48.970 & 46.630 & 51.310 & & 8.49 \\
\hline Jeong et al. (2012) & 47.500 & 45.903 & 49.017 & & 8.72 \\
\hline $\begin{array}{l}\text { Lucas-Carrasco et al. } \\
\text { (2011) a }\end{array}$ & 47.600 & 45.006 & 50.194 & & 8.41 \\
\hline $\begin{array}{l}\text { Lucas-Carrasco et al. } \\
\text { (2011) b }\end{array}$ & 46.400 & 43.876 & 48.924 & & 8.43 \\
\hline Phillips et al. (2009) & 46.400 & 43.905 & 48.895 & & 8.44 \\
\hline $\begin{array}{l}\text { Rassi-Femandes al. } \\
\text { (2015) }\end{array}$ & 45.340 & 39.437 & 51.243 & & 6.87 \\
\hline Stefane et al. (2013) & 44.100 & 39.921 & 48.279 & & 7.74 \\
\hline Grouped & 49.465 & 46.221 & 52.708 & & \\
\hline Heterogen eity $\left(I^{2}\right)$ & \multicolumn{3}{|c|}{96.80} & 35.00 & \\
\hline \multicolumn{6}{|l|}{ Psychological Domain } \\
\hline Badenhorst et al. (2018) & 75.600 & 72.212 & 78.988 & \multirow{13}{*}{$1 \quad y$} & 8.19 \\
\hline Chang et al. (2012) & 46.940 & 45.600 & 48.280 & & 8.55 \\
\hline Choi et al. (2013) & 50.770 & 49.184 & 52.356 & & 8.52 \\
\hline $\begin{array}{ll}\text { Dajpratham } & \text { and } \\
\text { Kongk asuw an (2011) }\end{array}$ & 65.520 & 62.773 & 68.267 & & 8.33 \\
\hline $\begin{array}{l}\text { Estralla-Castillo and } \\
\text { Gómez-de-Regil (2015) a }\end{array}$ & 62.150 & 60.607 & 63.633 & & 8.53 \\
\hline $\begin{array}{l}\text { Estralla-Castillo and } \\
\text { Gómez-de-Regil (2015) b }\end{array}$ & 59.450 & 57.135 & 61.747 & & 8.42 \\
\hline Jeong et al. (2012) & 50.800 & 49.216 & 52.384 & & 8.52 \\
\hline $\begin{array}{l}\text { Lucas-Carrasco et al. } \\
\text { (2011) a }\end{array}$ & 53.000 & 50.011 & 55.989 & & 8.28 \\
\hline $\begin{array}{l}\text { Lucas-Carrasco de al. } \\
\text { (2011) b }\end{array}$ & 51.800 & 49.188 & 54.412 & & 8.36 \\
\hline Phillips et al. (2009) & 51.800 & 49.219 & 54.381 & & 8.37 \\
\hline $\begin{array}{l}\text { Rassi-Femandes et al. } \\
\text { (2015) }\end{array}$ & 63.950 & 59.069 & 68.831 & & 7.77 \\
\hline Stefane et al. (2013) & 61.400 & 57.818 & 64.982 & & 8.14 \\
\hline Grouped & 57.654 & 53.326 & 61.982 & & \\
\hline Heterogen eity $\left(I^{2}\right)$ & \multicolumn{3}{|c|}{97.91} & \multicolumn{2}{|l|}{70.00} \\
\hline
\end{tabular}

Figure 2: Combined mean scores for the four domains of the WHOQOL-BREF. 


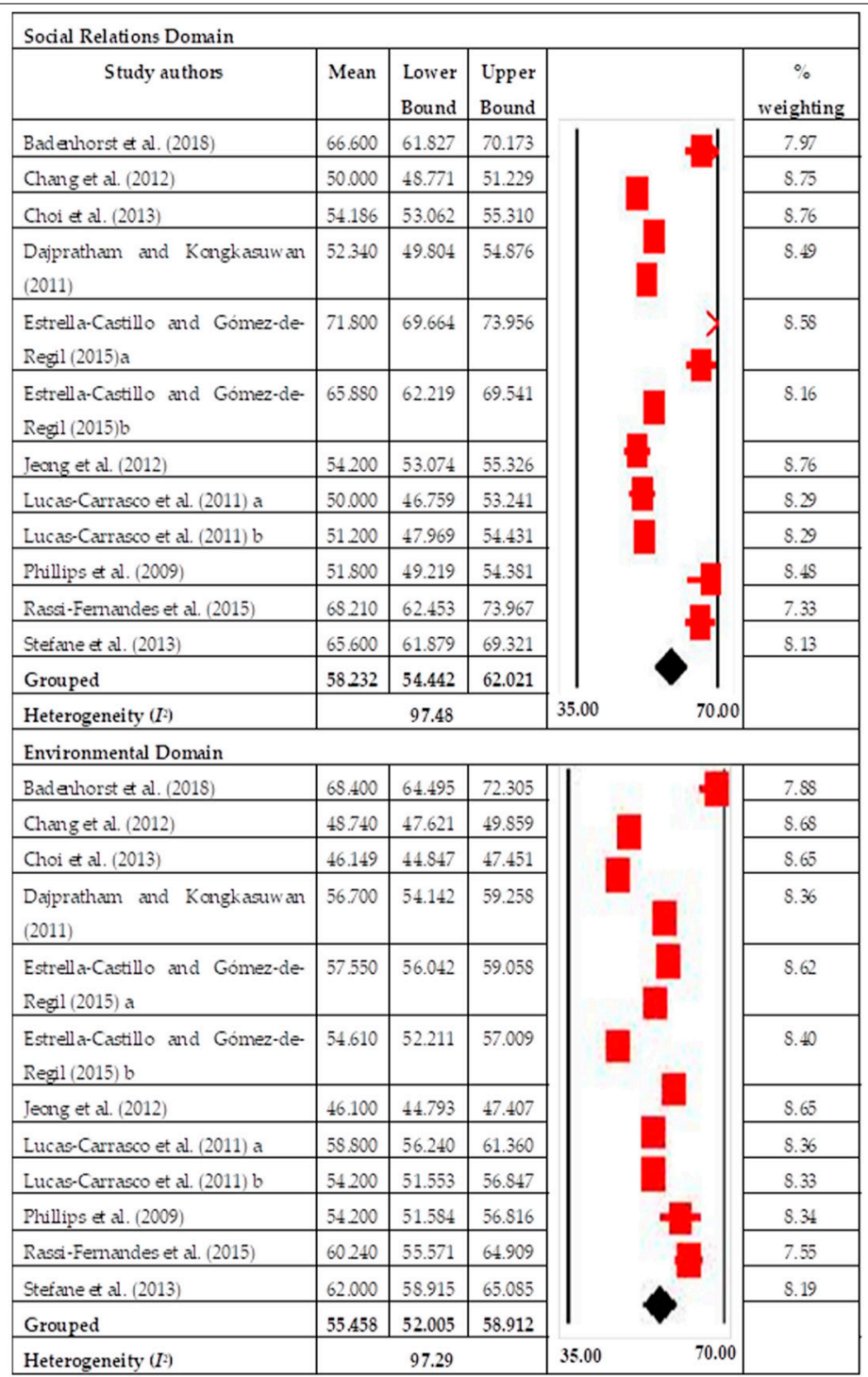

Figure 2 (Continued): Combined mean scores for the four domains of the WHOQOL-BREF.

\section{Table 3}

Subgroup analysis for the four domains of the WHOQOL-BREF based on descriptive and methodological characteristics of the studies

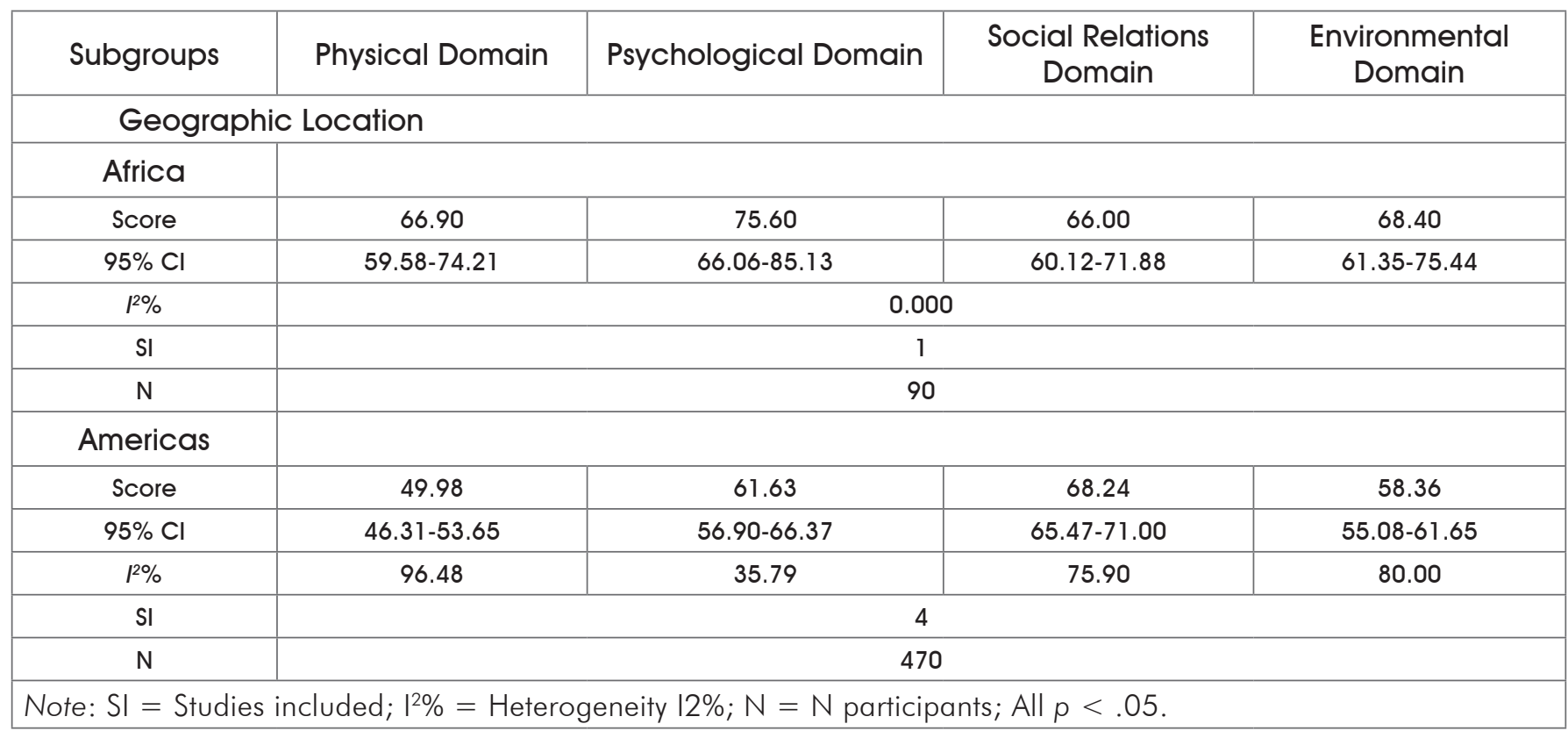




\section{Table 3 (Continued)}

Subgroup analysis for the four domains of the WHOQOL-BREF based on descriptive and methodological characteristics of the studies

\begin{tabular}{|c|c|c|c|c|}
\hline Subgroups & Physical Domain & $\begin{array}{l}\text { Psychological } \\
\text { Domain }\end{array}$ & $\begin{array}{c}\text { Social Relations } \\
\text { Domain }\end{array}$ & $\begin{array}{l}\text { Environmental } \\
\text { Domain }\end{array}$ \\
\hline \multicolumn{5}{|l|}{ Asia } \\
\hline Score & 47.38 & 53.31 & 52.71 & 49.19 \\
\hline $95 \% \mathrm{Cl}$ & $44.04-50.72$ & $48.76-57.87$ & $50.50-54.92$ & $46.15-52.24$ \\
\hline $12 \%$ & 14.55 & 97.78 & 90.54 & 95.15 \\
\hline SI & \multicolumn{4}{|c|}{4} \\
\hline $\mathrm{N}$ & \multicolumn{4}{|c|}{1253} \\
\hline \multicolumn{5}{|l|}{ Europe } \\
\hline Score & 46.79 & 52.19 & 51.04 & 55.74 \\
\hline $95 \% \mathrm{Cl}$ & $42.78-50.80$ & $46.81-57.57$ & $48.08-53.99$ & $52.038-59.44$ \\
\hline $12 \%$ & 0.000 & 0.000 & 0.000 & 75.35 \\
\hline SI & \multicolumn{4}{|c|}{3} \\
\hline $\mathrm{N}$ & \multicolumn{4}{|c|}{235} \\
\hline \multicolumn{5}{|c|}{ Health problem or condition causing physical disability } \\
\hline \multicolumn{5}{|l|}{ CVA } \\
\hline Score & 47.48 & 50.78 & 54.19 & 46.12 \\
\hline $95 \% \mathrm{Cl}$ & $40.12-54.83$ & $37.23-64.33$ & $49.71-58.67$ & $39.07-53.17$ \\
\hline $12 \%$ & \multicolumn{4}{|c|}{0.000} \\
\hline SI & \multicolumn{4}{|c|}{2} \\
\hline $\mathrm{N}$ & \multicolumn{4}{|c|}{845} \\
\hline \multicolumn{5}{|l|}{$A C$} \\
\hline Score & 45.34 & 63.95 & 68.21 & 60.24 \\
\hline $95 \% \mathrm{Cl}$ & $33.47-57.20$ & $44.23-83.66$ & $59.72-76.69$ & $49.31-71.16$ \\
\hline $12 \%$ & \multicolumn{4}{|c|}{0.000} \\
\hline $\mathrm{SI}$ & \multicolumn{4}{|c|}{1} \\
\hline $\mathrm{N}$ & \multicolumn{4}{|c|}{43} \\
\hline $\begin{array}{l}\text { Vote: } \text { SI }=\text { Studie } \\
\text { All } p<.05\end{array}$ & ed; $\mid 2 \%=$ Heterog $\epsilon$ & $12 \% ; N=N$ par & its; CVA = stroke; & adhesive capsul \\
\hline
\end{tabular}


Table 3 (Continued)

Subgroup analysis for the four domains of the WHOQOL-BREF based on descriptive and methodological characteristics of the studies

\begin{tabular}{|c|c|c|c|c|}
\hline Subgroups & Physical Domain & $\begin{array}{l}\text { Psychological } \\
\text { Domain }\end{array}$ & $\begin{array}{c}\text { Social Relations } \\
\text { Domain }\end{array}$ & $\begin{array}{l}\text { Environmental } \\
\text { Domain }\end{array}$ \\
\hline \multicolumn{5}{|l|}{ CLBP } \\
\hline Score & 44.100 & 61.44 & 65.60 & 62.00 \\
\hline $95 \% \mathrm{Cl}$ & $32.99-55.20$ & $41.97-80.83$ & $58.33-72.86$ & $51.65-72.35$ \\
\hline $12 \%$ & \multicolumn{4}{|c|}{0.000} \\
\hline $\mathrm{SI}$ & \multicolumn{4}{|c|}{1} \\
\hline $\mathrm{N}$ & \multicolumn{4}{|c|}{97} \\
\hline \multicolumn{5}{|l|}{ MS } \\
\hline Score & 46.40 & 51.80 & 51.51 & 54.20 \\
\hline $95 \% \mathrm{Cl}$ & $38.91-53.88$ & $38.17-65.42$ & $46.64-56.37$ & $46.97-61.43$ \\
\hline $12 \%$ & \multicolumn{4}{|c|}{0.000} \\
\hline SI & \multicolumn{4}{|c|}{2} \\
\hline $\mathrm{N}$ & \multicolumn{4}{|c|}{170} \\
\hline \multicolumn{5}{|l|}{$\mathrm{SCl}$} \\
\hline Score & 53.49 & 62.56 & 55.20 & 57.51 \\
\hline $95 \% \mathrm{Cl}$ & $47.38-59.59$ & $51.43-73.68$ & $51.26-59.13$ & $51.59-63.42$ \\
\hline $12 \%$ & 98.20 & 99.39 & 96.19 & 98.19 \\
\hline $\mathrm{SI}$ & \multicolumn{4}{|c|}{3} \\
\hline $\mathrm{N}$ & \multicolumn{4}{|c|}{498} \\
\hline \multicolumn{5}{|l|}{ MS/CTD } \\
\hline Score & 57.78 & 62.12 & 71.80 & 57.55 \\
\hline $95 \% \mathrm{Cl}$ & $47.43-68.13$ & $42.96-81.27$ & $65.20-78.39$ & $47.55-67.54$ \\
\hline $12 \%$ & \multicolumn{4}{|c|}{0.000} \\
\hline SI & \multicolumn{4}{|c|}{1} \\
\hline $\mathrm{N}$ & \multicolumn{4}{|c|}{229} \\
\hline \multicolumn{5}{|l|}{ PK } \\
\hline Score & 47.60 & 53 & 50 & 58.80 \\
\hline $95 \% \mathrm{Cl}$ & $36.98-58.21$ & $33.67-72.33$ & 42.97-57.02 & $48.59-69.00$ \\
\hline $12 \%$ & \multicolumn{4}{|c|}{0.000} \\
\hline $\mathrm{SI}$ & \multicolumn{4}{|c|}{1} \\
\hline $\mathrm{N}$ & \multicolumn{4}{|c|}{65} \\
\hline \multicolumn{5}{|l|}{ DNS } \\
\hline Score & 48.97 & 59.45 & 65.88 & 54.61 \\
\hline $95 \% \mathrm{Cl}$ & $38.41-59.52$ & $40.21-78.68$ & $58.64-73.11$ & $44.44-64.77$ \\
\hline $12 \%$ & \multicolumn{4}{|c|}{0.000} \\
\hline $\mathrm{SI}$ & \multicolumn{4}{|c|}{1} \\
\hline $\mathrm{N}$ & \multicolumn{4}{|c|}{101} \\
\hline $\begin{array}{l}\text { Note: } \mathrm{SI}=\text { Studies incl } \\
\text { cord injuries; MS/CTD } \\
\text { system. All } p<.05\end{array}$ & $\begin{array}{l}\%=\text { Heterogeneity } 12 \% ; \\
\text { ses of the musculoskeleto }\end{array}$ & $\begin{array}{l}\text { participants; } C L B P= \\
m \text { and connective tiss }\end{array}$ & $\begin{array}{l}\text { low back pain; } M S=1 \\
=\text { Parkinson's disease; } D\end{array}$ & $\begin{array}{l}\text { sclerosis; } \mathrm{SCl}=\text { spir } \\
\text { diseases of the nervo }\end{array}$ \\
\hline
\end{tabular}




\begin{tabular}{|c|c|c|c|c|}
\hline \multicolumn{5}{|c|}{$\begin{array}{c}\text { Table } 3 \text { (Continued) } \\
\text { Subgroup analysis for the four domains of the WHOQOL-BREF based on descriptive and methodological } \\
\text { characteristics of the studies }\end{array}$} \\
\hline Subgroup & Physical Domain & $\begin{array}{l}\text { Psychological } \\
\text { Domain }\end{array}$ & $\begin{array}{l}\text { Social Relations } \\
\text { Domain }\end{array}$ & $\begin{array}{c}\text { Environmental } \\
\text { Domain }\end{array}$ \\
\hline \multicolumn{5}{|c|}{ Recruitment scope } \\
\hline \multicolumn{5}{|c|}{ Community scope } \\
\hline Score & 56.47 & 63.56 & 58.71 & 61.12 \\
\hline $95 \% \mathrm{Cl}$ & $47.50-65.45$ & $53.36-73.75$ & $48.62-68.80$ & $51.84-70.41$ \\
\hline $12 \%$ & 98.89 & 99.16 & 96.89 & 97.14 \\
\hline $\mathrm{SI}$ & \multicolumn{4}{|c|}{2} \\
\hline $\mathrm{N}$ & \multicolumn{4}{|c|}{176} \\
\hline \multicolumn{5}{|c|}{ Hospital scope } \\
\hline Score & 48.01 & 57.56 & 59.11 & 55.03 \\
\hline $95 \% \mathrm{Cl}$ & $43.78-52.24$ & $52.76-62.35$ & $54.38-63.85$ & $50.71-59.36$ \\
\hline $12 \%$ & 96.59 & 96.57 & 97.54 & 97.39 \\
\hline $\mathrm{sl}$ & \multicolumn{4}{|c|}{9} \\
\hline $\mathrm{N}$ & \multicolumn{4}{|c|}{1.531} \\
\hline \multicolumn{5}{|l|}{ Mixed } \\
\hline Score & 48.44 & 46.94 & 50 & 48.74 \\
\hline $95 \% \mathrm{Cl}$ & $36.03-60.84$ & $32.77-61.10$ & $36.10-63.89$ & $35.98-61.50$ \\
\hline $12 \%$ & \multicolumn{4}{|c|}{0.000} \\
\hline $\mathrm{SI}$ & \multicolumn{4}{|c|}{1} \\
\hline $\mathrm{N}$ & \multicolumn{4}{|c|}{341} \\
\hline \multicolumn{5}{|l|}{ Design } \\
\hline \multicolumn{5}{|l|}{ Cohort } \\
\hline Score & 46.53 & 57.10 & 60.73 & 52.71 \\
\hline $95 \% \mathrm{Cl}$ & $37.93-55.13$ & $45.65-68.56$ & $49.83-71.64$ & $43.92-61.49$ \\
\hline $2 \%$ & 0.000 & 96.03 & 95.43 & 96.94 \\
\hline $\mathrm{SI}$ & \multicolumn{4}{|c|}{2} \\
\hline $\mathrm{N}$ & \multicolumn{4}{|c|}{465} \\
\hline \multicolumn{5}{|c|}{ Cross-sectional } \\
\hline Score & 50.00 & 57.77 & 57.80 & 56.00 \\
\hline $95 \% \mathrm{Cl}$ & $46.29-53.71$ & $52.71-68.84$ & $53.00-62.60$ & $52.13-59.86$ \\
\hline $12 \%$ & 97.22 & 98.16 & 97.83 & 97.16 \\
\hline $\mathrm{sl}$ & \multicolumn{4}{|c|}{10} \\
\hline $\mathrm{N}$ & \multicolumn{4}{|c|}{1.583} \\
\hline \multicolumn{5}{|c|}{ Recruitment method } \\
\hline \multicolumn{5}{|l|}{ Database } \\
\hline Score & 56.47 & 63.56 & 58.71 & 61.12 \\
\hline $95 \% \mathrm{Cl}$ & $47.50-65.45$ & $53.36-73.75$ & $48.62-68.80$ & $51.84-70.41$ \\
\hline $12 \%$ & 98.89 & 99.16 & 96.84 & 97.14 \\
\hline $\mathrm{sl}$ & \multicolumn{4}{|c|}{2} \\
\hline $\mathrm{N}$ & \multicolumn{4}{|c|}{176} \\
\hline Note: $\mathrm{SI}=$ Studie & $12 \%=$ Heterogeneity & $N=N$ participants & $<.05$ & \\
\hline
\end{tabular}




\section{Table 3 (Continued)}

Subgroup analysis for the four domains of the WHOQOL-BREF based on descriptive and methodological characteristics of the studies

\begin{tabular}{|c|c|c|c|c|}
\hline Subgroups & Physical Domain & $\begin{array}{l}\text { Psychological } \\
\text { Domain }\end{array}$ & $\begin{array}{c}\text { Social Relations } \\
\text { Domain }\end{array}$ & $\begin{array}{c}\text { Environmental } \\
\text { Domain }\end{array}$ \\
\hline \multicolumn{5}{|c|}{ Direct recruitment } \\
\hline Score & 48.01 & 57.56 & 59.11 & 55.03 \\
\hline $95 \% \mathrm{Cl}$ & $43.79-52.24$ & $52.76-62.35$ & $54.38-63.85$ & $50.71-59.36$ \\
\hline $12 \%$ & 95.59 & 96.57 & 97.54 & 97.39 \\
\hline SI & \multicolumn{4}{|c|}{9} \\
\hline $\mathrm{N}$ & \multicolumn{4}{|c|}{1.531} \\
\hline \multicolumn{5}{|l|}{ Mixed } \\
\hline Score & 48.44 & 46.94 & 50.00 & 48.74 \\
\hline $95 \% \mathrm{Cl}$ & $36.03-60.84$ & $32.77-61.10$ & $36.10-63.89$ & $35.98-61.50$ \\
\hline $12 \%$ & \multicolumn{4}{|c|}{0.000} \\
\hline $\mathrm{SI}$ & \multicolumn{4}{|c|}{1} \\
\hline $\mathrm{N}$ & \multicolumn{4}{|c|}{341} \\
\hline \multicolumn{5}{|c|}{ Exclusion criteria } \\
\hline \multicolumn{5}{|l|}{ No } \\
\hline Score & 47.43 & 49.33 & 50.88 & 51.42 \\
\hline $95 \% \mathrm{Cl}$ & $39.12-55.74$ & $39.69-58.98$ & $41.70-60.06$ & $42.22-60.62$ \\
\hline $12 \%$ & 50.70 & 90.67 & 34.32 & 92.93 \\
\hline $\mathrm{SI}$ & \multicolumn{4}{|c|}{2} \\
\hline $\mathrm{N}$ & \multicolumn{4}{|c|}{427} \\
\hline \multicolumn{5}{|l|}{ Yes } \\
\hline Score & 49.87 & 59.32 & 59.76 & 56.31 \\
\hline $95 \% \mathrm{Cl}$ & $46.09-53.65$ & $54.96-63.68$ & $55.57-63.94$ & $52.16-60.47$ \\
\hline $12 \%$ & 97.18 & 97.46 & 97.39 & 97.59 \\
\hline SI & \multicolumn{4}{|c|}{10} \\
\hline $\mathrm{N}$ & \multicolumn{4}{|c|}{1.621} \\
\hline \multicolumn{5}{|c|}{ Response rate } \\
\hline \multicolumn{5}{|l|}{ No } \\
\hline Score & 45.95 & 59.06 & 57.17 & 56.57 \\
\hline $95 \% \mathrm{Cl}$ & $40.98-50.92$ & $52.23-65.88$ & $51.01-63.34$ & $50.25-62.88$ \\
\hline $12 \%$ & 0.000 & 94.31 & 94.28 & 75.86 \\
\hline $\mathrm{SI}$ & \multicolumn{4}{|c|}{5} \\
\hline $\mathrm{N}$ & \multicolumn{4}{|c|}{356} \\
\hline \multicolumn{5}{|l|}{ Yes } \\
\hline Score & 51.79 & 56.68 & 58.97 & 53.31 \\
\hline $95 \% \mathrm{Cl}$ & $47.75-55.84$ & $51.00-62.36$ & $53.87-64.07$ & $48.88-57.73$ \\
\hline $12 \%$ & 97.96 & 98.60 & 97.39 & 97.84 \\
\hline $\mathrm{SI}$ & \multicolumn{4}{|c|}{7} \\
\hline $\mathrm{N}$ & \multicolumn{4}{|c|}{1.692} \\
\hline
\end{tabular}




\section{Table 3 (Continued)}

Subgroup analysis for the four domains of the WHOQOL-BREF based on descriptive and methodological characteristics of the studies

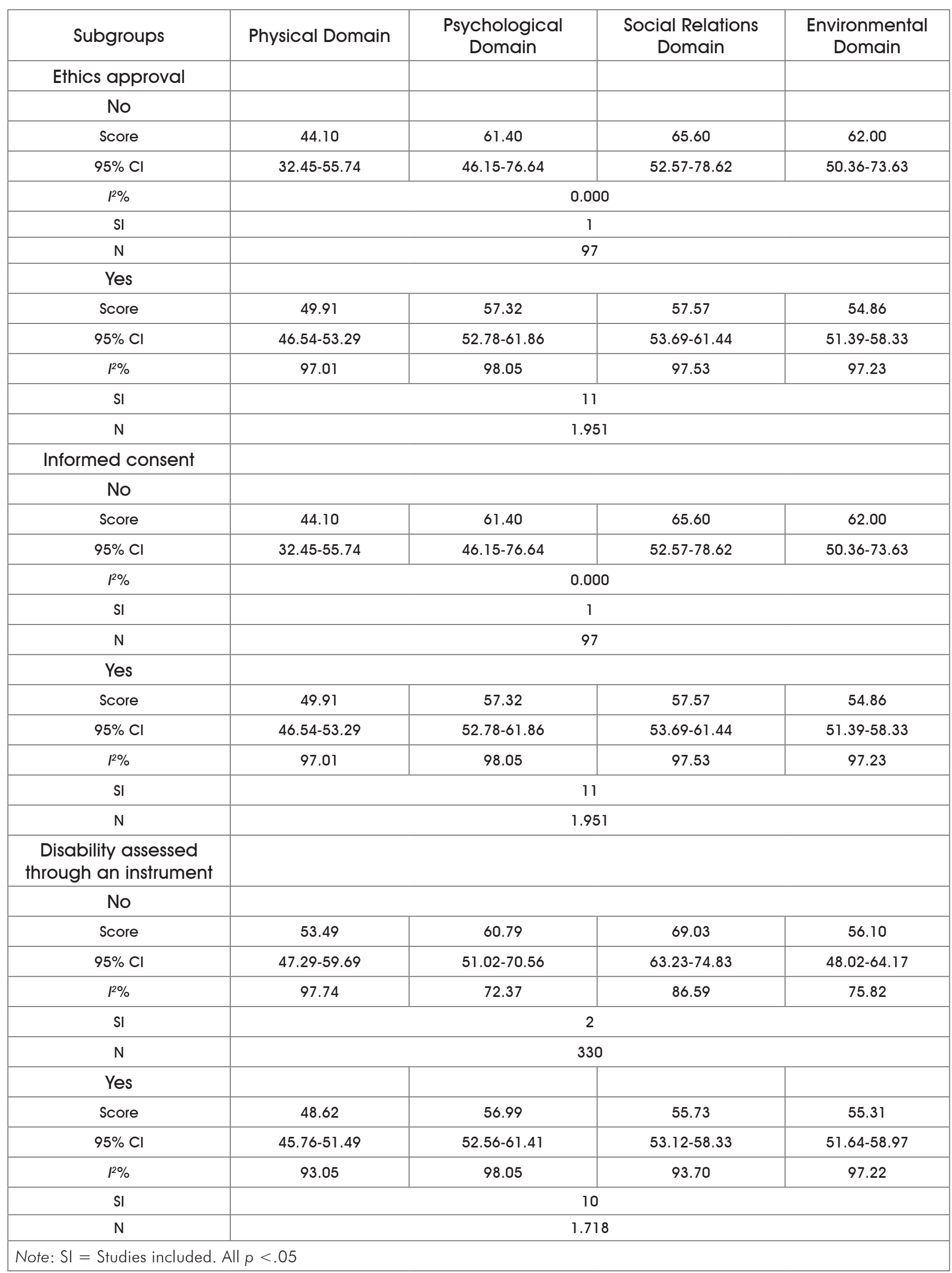


Statistically significant differences were found between the study conducted in Africa and those conducted in the other locations. Statistically significant differences were identified based on differences in physical ailment: the studies where the cause of disability was adhesive capsulitis, chronic low back pain, or multiple sclerosis; studies where the cause was a spinal cord injury or diseases of the musculoskeletal system and connective tissue; studies where the cause of disability was diseases of the musculoskeletal system and connective tissue and those where the cause of disability was stroke, adhesive capsulitis, chronic low back pain, or multiple sclerosis. Statistically significant differences were also identified depending on the sample population: studies where the scope of recruitment was community vs. those where the scope was hospital patients; studies where the participants were recruited through a database vs. those where participants were recruited directly through the health care system. Finally, statistically significant differences were also noted depending on study-specific methodological variables: studies that did not report the response rate vs. those that did; studies that did not obtain ethical approval vs. those that did; and studies where the disability was not evaluated using an assessment instrument vs. those that were.

PSYCHOLOGICAL DOMAIN. Scores were higher when the study region was Africa, the problem causing disability was adhesive capsulitis, the scope of recruitment was community, the design was cross-sectional, participants were contacted through a database, the inclusion criteria were reported, the response rate was not reported, no ethical approval or informed consent were obtained, and the disability was assessed through other appropriate diagnostic criteria $(p<.05)$. Statistically significant differences were found depending on study location: studies conducted in Africa differed from those conducted in the other locations; and studies conducted in the Americas differed from those conducted in Asia and Europe. Psychological domain differences were also statistically significant in studies where the main cause of disability was stroke vs. those where it was spinal cord injury. Statistically significant differences were also identified depending on the study characteristics: studies whose scope of recruitment was community vs. hospital patients or mixed; studies where the scope of recruitment was mixed vs. hospital-based recruitment; studies where the participants were recruited through a database vs. those where participants were recruited through the health care system or through a mixed procedure; and studies that did not clearly establish the inclusion criteria vs. those that did.

SOCIAL RELATIONS DOMAIN. Scores were higher when the study region was the Americas, the disability was due to musculoskeletal disease, the recruitment scope was health care, the design was cohort, patients were recruited through health care providers, the exclusion criteria and response rate were reported, ethical approval and informed consent were not obtained, and disability was assessed through other appropriate diagnostic criteria $(p<.05)$. Statistically significant differences were found depending on study location: studies conducted in Africa and the Americas vs. those conducted in Asia and Europe. There were also differences in the social relations domain depending on physical ailment: studies where the cause of disability was stroke, multiple sclerosis, spinal cord injury, or Parkinson's disease vs. those studies where the cause of disability was adhesive capsulitis, chronic low back pain, diseases of the musculoskeletal system and connective tissue, or diseases of the nervous system; differences in studies where the cause of disability was Parkinson's disease vs. the study where the cause of disability was spinal cord injury. Differences in the social relations domain were also evident depending study characteristics: studies where the scope of recruitment was mixed vs. those where it was community or hospital; studies that did not clearly establish the inclusion criteria vs. those that did; studies that did not obtain ethical approval vs. those that did; studies that did not obtain informed consent vs. those that did; and studies where the disability was not evaluated through an assessment instrument vs. those that did.

ENVIRONMENTAL DOMAIN. Scores were higher when the study region was Africa, the physical disability was due to chronic low back pain, the recruitment scope was community, 
the design was cross-sectional, participants were recruited through a database, exclusion criteria were reported, the response rate was not reported, ethical approval and informed consent were not obtained, and disability was assessed through other appropriate diagnostic criteria ( $p$ $<$.05). Statistically significant differences were found depending on study location: studies conducted in Africa and Asia vs. those conducted in the Americas and Europe. Differences were also identified based on physical ailment: studies where the cause of disability was stroke vs. those where the cause of disability was adhesive capsulitis, chronic low back pain, multiple sclerosis, spinal cord injury, diseases of the musculoskeletal system and connective tissue, and Parkinson's disease; studies where the main cause of disability was chronic low back pain vs. the studies where it was multiple sclerosis; and studies where the main cause of disability was diseases of the nervous system vs. studies where it was stroke. Statistically significant differences also were evident depending on study characteristics: studies where the scope of recruitment was community vs. those where it was hospital patients; studies where the scope of recruitment was mixed vs. other scopes of recruitment; studies where the participants were recruited through a database and those where they were recruited directly through the health care system; studies where the recruitment method was mixed vs. the rest of the studies; studies that did not clearly establish the inclusion criteria vs. those that did; studies that did not obtain ethical approval vs. those that did; and studies that did not obtain informed consent vs. those that did.

In relation to the analysis of quantitative moderating variables (age, percentage of women, and risk of bias score), meta-regression analyses did not uncover significant associations with any of the four domains of the WHOQOLBREF.

\section{-ASSESSMENT OF PUBLICATION BIAS}

The Egger test was used to investigate the presence of publication bias. Potential publication bias was found for the psychological $(p=.036)$ and environment $(p=.001)$ domains.

\section{DISCUSSION}

The main objective of this study was to systematically analyze all published articles that evaluated HRQL in people with physical disabilities by providing pooled mean scores for the four domains of the WHOQOL-BREF. Ten studies were analyzed, with a total sample of 2,048 participants, an average of 235.4 per study. The participants were predominantly middle-aged and $50.9 \%$ were women. The majority of the participants came from Asia and presented spinal cord injury as the cause of physical disability, followed by those in which the disability was derived from a stroke. The preferred method for contacting participants was through a health care context.

In relation to the global profile of persons with disabilities, in recent decades there has been an unprecedented increase in survival in Asia, with life expectancy increasing from 36 years to 66 years between 1970 and 2010 (Institute for Health Metrics and Evaluation [IHME], 2013); disability-adjusted life years has increased in parallel. However, this review found a causeof-disability profile that contrasts with the data obtained for the general profile of middle-aged adults with disabilities, whose primary cause of disability-adjusted life years was musculoskeletal disorders (IHME, 2013). One possible explanation lies in the greater severity of spinal cord injuries and their potential to generate more severe degrees of disability, making them the object of research focusing on HRQL in people with diseases that are potentially disabling (e.g., Badenhorst et al., 2018; Barker et al., 2009; Sakakibara et al., 2012; van Leeuwen et al., 2012).

In relation to the methodological characteristics of the works included in this review, most used a cross-sectional design and none of them made a previous estimate of sample size. All of them reported the method of recruitment, predominantly occurring through the health care field. All the previous research established clear inclusion criteria and a large majority also explained their exclusion criteria. More than a half of the studies provided data that allowed the response rate to be calculated. The majority reported that ethical approval and that informed 
consent had been obtained. The majority also assessed disability using specific instruments, but one study (Estrella-Castillo \& Gómez-deRegil, 2016) indicated that the sample consisted of people with physical disabilities evaluated according to internationally accepted criteria. These findings show a high level of methodological quality, consistent with the guidelines proposed by STROBE for reporting observational studies (von Elm et al., 2007), and with the data obtained for the assessment of the risk of bias using the RTI (Viswanathan et al., 2013).

Regarding the results of the meta-analysis, the pooled means for the WHOQOL-BREF were 49.5 for the physical domain, 57.7 for psychological, 58.2 for social relations, and 55.5 for environmental. Although there are no specific cut-off points for each of the WHOQOLBREF HRQL domains, the pooled means for all domains were lower than the scores obtained for the controls in studies that used people without physical disabilities as controls (e.g., Barker et al., 2009) which indicates an impact on all areas of HRQL. This is consistent with the findings of previous studies on the consequences of diseases with the potential to cause physical disability (e.g.; Carter et al., 2012; Craig et al., 2015; Jones et al., 2014).

There was a great deal of heterogeneity among the studies included in this meta-analysis. In general terms, the results were better for all HRQL domains when the study was located in Africa, with the exception of the social relations domain, for which better results were obtained in the work conducted in the Americas. The finding that the study carried out in Africa by Badenhorst et al. (2018) yielded higher scores in all areas except social could be explained by its use of a population of former rugby players; it is likely that their identity as athletes represents a means to improve their adjustment to disability, to maintain their physical activity over the long term, and to decrease the negative consequences of inactivity such as depression and anxiety (Sahlin \& Lexell, 2015). Likewise, the fact that scores for the social relations domain were higher in studies conducted in the Americas could reflect the strong family ties and frequent interactions among members of the extended family that are characteristic of Hispanic culture (Wilmoth, 2001).
In relation to the cause of disability, $H R Q L$ scores were higher for the physical and the social relations domains when the cause of disability was a musculoskeletal disease. Scores were higher for the psychological domain for persons with adhesive capsulitis, and for the environmental domain among those with chronic low back pain. The lowest score for the psychological and environmental domains corresponding to persons who had experienced a stroke and for social relations was persons with Parkinson's disease. This seems to indicate that different pathologies affect different domains within quality of life differently. Consistent with findings on stroke and Parkinson's disease, previous studies reported that stroke patients may suffer psychiatric manifestations such as depression, anxiety and fatigue (Hackett, Köhler, $O^{\prime}$ 'Brien, \& Mead, 2014). As for Parkinson's patients, the results are consistent with previous work (Miller, Noble, Jones, Allcock, \& Burn, 2008) that found that communication deficits limit their social relationships.

Participants recruited from the community obtained better scores on all domains except for social relations. These findings coincide with previous work (Jovanović, Lakićević, Stevanović, Milić-Rasić, \& Slavnić, 2012), which found that this group of participants showed a HRQL similar to that of the general population and higher than that of people with disabilities recruited in health care settings. In the social relations domain, the highest scores were achieved when the recruitment scope was health care settings, which suggests the possible influence of perceptions on the responsiveness of health care personnel and the link established between patients and their doctors (Holmqvist \& von Koch, 2001).

In relation to methodological characteristics, HRQL was higher in all areas when the design was cross-sectional, except for the social relations domain, where scores were higher in the cohort studies. Higher scores were obtained in all areas when participants were recruited through a database, except in the social relations domain, where a higher HRQL was obtained when participants were recruited directly from health care settings. HRQL was higher in all domains when the exclusion criteria were reported. This measure was higher in the physical and social 
relations domains when data on response rate were provided, but higher in the psychological and environmental domains when response rate was not provided. In general terms, that the higher the methodological quality of the study according to the STROBE guidelines (von Elm et al., 2007), the higher the HRQL scores. One seemingly contradictory finding is that in all domains except physical, scores were higher when no ethical approval or informed consent was obtained. This could be related to a greater propensity to take this methodological consideration into account when participants were recruited from health care contexts; such participants, requiring regular medical contact, may have an overall greater severity of physical disability.

The results of our work should be interpreted in the light of certain limitations. First, the number of studies included was relatively small. In addition, the wide variety of instruments used to determine the severity of physical disability in the different investigations prevented analysis of this variable as a potential source of heterogeneity. On the other hand, it is worth mentioning that one of the main strengths of this work is that it is the first literature review and meta-analysis to provide pooled mean scores for the four domains of the WHOQOL-BREF among people with physical disabilities, to include a rigorous assessment of the methodological quality and risk of bias, to use rigorous methods of quantitative synthesis to examine sources of heterogeneity, and to submit its protocol to a registry.

The aforementioned findings indicate that in order to achieve a better understanding of the consequences of living with a disability, we need more studies with greater methodological rigor, controls for possible selection biases, larger samples, and detailed assessment of disability and HRQL. This information is relevant to the design of effective interventions to mitigate the effects of living with a disability on HRQL.

\section{- Conflict of interest}

The authors declare no conflict of interest.

\section{- Funding:}

This research was funded by the University of Cuenca, Ecuador.

\section{REFERENCES}

[References marked with an asterisk indicate studies included in the systematic review and meta-analysis]

*Badenhorst, M., Brown, J. C., Lambert, M. I., Mechelen, W. V., \& Verhagen, E. (2018). Quality of life among individuals with rugbyrelated spinal cord injuries in South Africa: $A$ descriptive crossectional study. BMJ Open, 8, e020890. https://doi.org/10.1136/ bmiopen-2017-020890

Barker, R. N., Kendall, M. D., Amsters, D. I., Pershouse, K. J., Haines, T. P., \& Kuipers, P. (2009). The relationship between quality of life and disability across the lifespan for people with spinal cord injury. Spinal Cord, 47(2), 149-155. https://doi.org/10.1038/ sc. 2008.82

Borenstein, M., Hedges, L., Higgins, J., \& Rothstein, H. (2005). Comprehensive MetaAnalysis (Version 2.0) [Computer Software]. Biostat: Englewood (NJ), United States.

Carter, G. T., Miró, J., Abresch, R. T., El-Abassi, R., \& Jensen, M. P. (2012). Disease burden in neuromuscular disease: the role of chronic pain. Physical Medicine and Rehabilitation Clinics of North America, 23(3), 719-729. https://doi.org/10.1016/i.pmr.2012.06.004

*Chang, F.-H., Wang, Y.-H., Jang, Y., \& Wang, C.-W. (2012). Factors associated with quality of life among people with spinal cord injury: application of the International Classification of Functioning, Disability and Health model. Archives of Physical Medicine and Rehabilitation, 93(12), 2264-2270. https:// doi.org/10.1016/i.apmr.2012.06.008

${ }^{*}$ Choi, D.-H., Jeong, B.-O., Kang, H.-J., Kim, S.-W., Kim, J.-M., Shin, I.-S.,...Yoon, J.-S. (2013). Psychiatric comorbidity and quality of life in patients with post-stroke emotional incontinence. Psychiatry Investigation, 10(4), 382-387. https://doi.org/10.4306/ pi.2013.10.4.382

Craig, A., Nicholson Perry, K., Guest, R., Tran, Y., \& Middleton, J. (2015). Adjustment following chronic spinal cord injury: Determining factors that contribute to social participation. British 
Journal of Health Psychology, 20(4), 807-823. https://doi.org/10.1111/bihp.12143

*Dajpratham, P., \& Kongkasuwan, R. (2011). Quality of life among the traumatic spinal cord injured patients. Journal of the Medical Association of Thailand, 94(10), 1252-1259.

Deeks, J. J., Dinnes, J., D’Amico, R., Snowden, A. J., Sakarovitch, C., Song, F.,...Altman. D. G. (2003). Evaluating non-randomised intervention studies. Health Technology Assessment, 7, 1-173. https://doi. org/10.3310/hta7270

*Estrella-Castillo, D. \& Gómez-de-Regil, L. (2016). Quality of life in mexican patients with primary neurological or musculoskeletal disabilities. Disability and Health Journal, 9(1), 127-133. https://doi.org/10.1016/i.dhio.2015.05.003

Fariña, F., Arce, R., \& Novo, M. (2002). Heurístico de anclaje en las decisiones judiciales [Anchorage in judicial decision making]. Psicothema, 14, 39-46.

Hackett, M. L., Köhler, S., O’Brien, J. T., \& Mead, G. E. (2014). Neuropsychiatric outcomes of stroke. The Lancet Neurology, 13(5), 525-534. https://doi.org/10.1016/S14744422(14)70016-X

Hill, M. R., Noonan, V. K., Sakakibara, B. M., \& Miller, W. C. (2010). Quality of life instruments and definitions in individuals with spinal cord injury: a systematic review. Spinal Cord, 48(6), 438-450. https://doi.org/10.1038/ sc.2009.164

Holmqvist, L. W., \& von Koch, L. (2001). Environmental factors in stroke rehabilitation. BMJ (Clinical Research Ed.), 322(7301), 1501-1502. $\quad$ https://doi.org/10.1136/ bmi.322.7301.1501

Institute for Health Metrics and Evaluation [IHME] (2013). The Global Burden of Disease: Generating Evidence, Guiding Policy. Seattle, WA: IHME.

*Jeong, B.-O., Kang, H.-J., Bae, K.-Y., Kim, S.W., Kim, J.-M., Shin, I.-S.,...Yoon, J.-S. (2012). Determinants of quality of life in the acute stage following stroke. Psychiatry Investigation, 9(2), 127-133. https://doi.org/10.4306/ pi.2012.9.2.127
Jones, K. H., Jones, P. A., Middleton, R. M., Ford, D. V., Tuite-Dalton, K., Lockhart-Jones, H.,... Noble, J. G. (2014). Physical disability, anxiety and depression in people with MS: an internet-based survey via the UK MS Register. PloS One, 9(8), e104604. https://doi. org/10.1371/journal.pone.0104604

Jovanović, M., Lakićević, M., Stevanović, D., Milić-Rasić, V., \& Slavnić, S. (2012). Community-based study of health-related quality of life in spinal cord injury, muscular dystrophy, multiple sclerosis, and cerebral palsy. Disability and Rehabilitation, 34(15), 1284-1290. https://doi.org/10.3109/0963 8288.2011 .641659

Law, M., Hanna, S., Anaby, D., Kertoy, M., King, G., \& Xu, L. (2014). Health-related quality of life of children with physical disabilities: a longitudinal study. BMC Pediatrics, 14, 26. https://doi.org/10.1186/1471-2431-14-26

Liem, N. R., McColl, M. A., King, W., \& Smith, K. M. (2004). Aging with a spinal cord injury: factors associated with the need for more help with activities of daily living. Archives of Physical Medicine and Rehabilitation, 85(10), 1567-1577. https://doi.org/10.1016/i. apmr.2003.12.038

*Lucas-Carrasco, R., Pascual-Sedano, B., Galán, I., Kulisevsky, J., Sastre-Garriga, J., \& Gómez-Benito, J. (2011). Using the WHOQOL-DIS to measure quality of life in persons with physical disabilities caused by neurodegenerative disorders. NeuroDegenerative Diseases, 8(4), 178-186. https://doi.org/10.1159/000321582

Miller, N., Noble, E., Jones, D., Allcock, L., \& Burn, D. J. (2008). How do I sound to me? Perceived changes in communication in parkinson's disease. Clinical Rehabilitation, 22(1), 14-22. https://doi. org/10.1177/0269215507079096

Monteiro, A., Vázquez, M.J., Seijo, D., \& Arce, R. (2018). ¿̇Son los criterios de realidad válidos para clasificar y discernir entre memorias de hechos auto-experimentados y de eventos vistos en vídeo? [Are the reality criteria valid to classify and to discriminate between memories of self-experienced events and 
memories of video-observed events?]. Revista Iberoamericana de Psicología y Salud, 9 (2), 149-160. https://doi.org/10.23923/i. rips.2018.02.020

Murray, C. J. L., Vos, T., Lozano, R., Naghavi, M., Flaxman, A. D., Michaud, C., . . Memish, Z. A. (2012). Disability-adjusted life years (DALYs) for 291 diseases and injuries in 21 regions, 1990-2010: A systematic analysis for the global burden of disease study 2010. The Lancet, 380(9859), 2197-2223. https:// doi.org/10.1016/s0140-6736(12)61689. $\underline{4}$

Passier, P. E. C. A., Visser-Meily, J., Rinkel, G. J. E., Lindeman, E., \& Post, M. W. M. (2013). Determinants of health-related quality of life after aneurysmal subarachnoid hemorrhage: A systematic review. Quality of Life Research, 22(5), 1027-1043. https:// doi.org/10.1007/s $11136-012-0236-1$

*Phillips, L. H., Saldias, A., McCarrey, A., Henry, J. D., Scott, C., Summers, F., \& Whyte, M. (2009). Attentional lapses, emotional regulation and quality of life in multiple sclerosis. British Journal of Clinical Psychology, 48(1), 101-106. https://doi. org/10.1348/014466508X379566

*Rassi-Fernandes, M. (2015). Correlation between functional disability and quality of life in patients with adhesive capsulitis. Acta Ortopedica Brasileira, 23(2), 81 84. $\quad$ https://doi.org/10.1590/141378522015230200791

Redondo, L., Fariña, F., Seijo, D., Novo, M., \& Arce, R. (2019). A meta-analytical review of the responses in the MMPI-2/MMPI-2-RF clinical and restructured scales of parents in child custody dispute. Anales de Psicología, 35(1) 156-165. https://doi.org/10.6018/ analesps.35.1.338381

Sahlin, K. B., \& Lexell, J. (2015). Impact of organized sports on activity, participation, and quality of life in people with neurologic disabilities. PM \& R: The Journal of Injury, Function, and Rehabilitation, 7(10), 1081-1088. https://doi.org/10.1016/i. pmri.2015.03.019

Sakakibara, B. M., Hitzig, S. L., Miller, W. C., \&
Eng, J. J. (2012). An evidence-based review on the influence of aging with a spinal cord injury on subjective quality of life. Spinal Cord, 50(8), 570-578. https://doi.org/10.1038/ sc. 2012.19

Sinha, R., \& Van Den Heuvel, W. J. A. (2011). A systematic literature review of quality of life in lower limb amputees. Disability and Rehabilitation, 33(11), 883-899. https://doi. org/10.3109/09638288.2010.514646

Skevington, S. M., \& Epton, T. (2018). How will the sustainable development goals deliver changes in well-being? A systematic review and meta-analysis to investigate whether WHOQOL-BREF scores respond to change. BMJ Global Health, 3(Suppl 1), e000609. https://doi.org/10.1136/ bmigh-2017-000609

*Stefane, T., Munari dos Santos, A., Marinovic, A., \& Hortense, P. (2013). Chronic low back pain: pain intensity, disability and quality of life. Acta Paulista de Enfermagem, 26(1), 14-20. https://doi.org/10.1590/s010321002013000100004

Stroup, D. F., Berlin, J. A., Morton, S. C., Olkin, I., Williamson, G. D., Rennie, D.,... Thacker, S. B. (2000). Meta-analysis of observational studies in epidemiology: a proposal for reporting. Meta-analysis Of Observational Studies in Epidemiology (MOOSE) group. Journal of the American Medical Association, 283(15), 2008-2012. https://doi.org/10.1001/ jama.283.15.2008

The WHOQOL Group (1995). The world health organization quality of life assessment (WHOQOL): Position paper from the world health organization. Social Science \& Medicine, $41(10)$, 1403-1409. https://doi. org/10.1016/0277-9536(95)00112-K

The WHOQOL Group (1998). Development of the World Health Organization WHOQOLBREF quality of life assessment. Psychological Medicine, 28(3), 551-558. https://doi. org/10.1017/S0033291798006667

van Leeuwen, C. M. C., Kraaijeveld, S., Lindeman, E., \& Post, M. W. M. (2012). Associations between psychological factors and quality of life ratings in persons with spinal cord injury: 
a systematic review. Spinal Cord, 50(3), 174187. https://doi.org/10.1038/sc.2011.120 Vázquez, F. L., Otero, P., García-Casal, J. A., Blanco, V., Torres, Á. J., \& Arrojo, M. (2018). Efficacy of video game-based interventions for active aging. A systematic literature review and meta-analysis. PLoS ONE, 13(12), 24. https:// doi.org/10.1371/iournal.pone.0208192

Viswanathan, M., Berkman, N. D., Dryden, D. M., \& Hartling, L. (2013). Assessing Risk of Bias and Confounding in Observational Studies of Interventions or Exposures: Further Development of the RTI Item Bank [Internet]. Rockville, MD: Agency for Healthcare Research and Quality (US).

von Elm, E., Altman, D. G., Egger, M., Pocock, S. J., Gøtzsche, P. C., \& Vandenbroucke, J. P. (2007). The strengthening the reporting of observational studies in epidemiology (STROBE) statement: Guidelines for reporting observational studies. Preventive Medicine, 45(4), 247-251. https://doi.org/10.1016/i. ypmed.2007.08.012
Whiteneck, G., Meade, M. A., Dijkers, M., Tate, D. G., Bushnik, T., \& Forchheimer, M. B. (2004). Environmental factors and their role in participation and life satisfaction after spinal cord injury. Archives of Physical Medicine and Rehabilitation, 85(11), 1793-1803. https:// doi.org/10.1016/i.apmr.2004.04.024

Wilmoth, J. M. (2001). Living arrangements among older immigrants in the United States. The Gerontologist, 41 (2), 228-238. https:// doi.org/10.1093/geront/41.2.228

World Health Organization and The World Bank. (2010). World Report on Disability. Retrieved from: https:/www.who.int/disabilities/world report/2011/report.pdf.

Yang, X., Fan, D., Xia, Q., Wang, M., Zhang, X., Li, X., .. . Pan, F. (2016). The healthrelated quality of life of ankylosing spondylitis patients assessed by SF-36: A systematic review and meta-analysis. Quality of Life Research, 25(11), 2711-2723. https://doi. org/10.1007/s $11136-016-1345-z$ 